\title{
Study of Kana (Canna sp) and Butterfly (Bauhinia purpurea) Plants as Leading Absorbents (Pb)
}

\author{
Sunu Kuntjoro ${ }^{1}$, Fida Rachmadiarti ${ }^{2}$ \\ Departement of Biology \\ Universitas Negeri Surabaya \\ Surabaya, Indonesia \\ ${ }^{2}$ fidarachmadiarti@unesa.ac.id
}

\begin{abstract}
According to the Environment Project Agency (2007), about $25 \%$ of lead $(\mathrm{Pb})$ remains in the engine and the other $75 \%$ will pollute the air as exhaust fumes. Kana (Cana sp) and Butterfly plant (Bahuinia purpurea) are plants that are suitable for the needs of urban forest plants. Studies related to the potential of these two plants in absorbing heavy metals have not been many. The objectives of this research were to: evaluate the ability of $\mathbf{P b}$ accumulation on Kana and Butterfly leaves exposed to motor vehicle emissions on jalan Ahmad Yani, Diponegoro and Wiyung, Surabaya, Analyze the relationship between lead $\mathrm{Pb}$ accumulated in Kana and butterfly leaves with chlorophyll content produced. The results of the study on Lead (Pb) levels on the leaves of Bauhinia and Canna exposed to motor vehicle emissions on some of the highest roads in Surabaya are Bauhinia plants $(0.834 \pm 0.108)$. Ahmad Yani Street found a lot of $\mathrm{Pb}$ exposure in leaves $0.908 \pm 0.011 \mathrm{mg} / \mathrm{L}$ Bauhinia leaves higher than Canna leaves, which amounted to $34.677 \pm 2.663 \mathrm{mg} / \mathrm{I}$ for Bauhinia leaves and $16.733 \pm 2.913 \mathrm{mg} / \mathrm{l}$ for Canna leaves. Cana and Butterfly can accumulate $\mathrm{Pb}$ in leaves. The type of plant does not affect the $\mathbf{P b}$ levels in the leaves of Kana and Butterfly, but the planting location affects the $\mathrm{Pb}$ levels of both plants. The levels of $\mathrm{Pb}$ in the leaves of the two plants planted on jalan Ahmad Yani and Diponegoro are higher than those planted on the Wiyung road. Pd levels in leaves do not affect chlorophyll levels
\end{abstract}

\section{Keywords_Lead; Chlorophyll; Cana sp; Bauhinia purpurea}

\section{INTRODUCTION}

Surabaya has experienced air pollution, this can be seen in the average dust particles that pollute the air $0.267 \mathrm{mg} / \mathrm{m}^{3}$ $0.427 \mathrm{mg} / \mathrm{m}^{3}$. This concentration far exceeds the standards set by the World Health Organization (WHO) that the maximum dust parameter is $0.02 \mathrm{mg} / \mathrm{m}^{3}$. The main cause of air pollution is the increasing number of motorized vehicles in Surabaya [2]. One of these particles is Lead $(\mathrm{Pb})$.

Lead $(\mathrm{Pb})$ in the form of gas mainly comes from burning gasoline additives from motorized vehicles [5]. In addition to $\mathrm{Pb}$, pollutants contained in motor vehicle exhaust gas are carbon monoxide (CO), hydrocarbon compounds, nitrogen oxides (NOx), sulfur (SOx) and other dust particulates [12]. Every 0.1 gram of lead $(\mathrm{Pb})$ per liter of gasoline can increase the octane number from 1.5 to 2 units [22]. Every liter of premium gasoline and super gasoline contains 0.70 grams of Tetraethyl $\mathrm{Pb}$ compound and 0.84 grams of Tetramethyl $\mathrm{Pb}$.
Every single liter of gasoline that is burned if converted will emit 0.56 grams of $\mathrm{Pb}$ which is discharged into the air $[1,13]$. The quality standard issued by the government regarding the lead compound $(\mathrm{Pb})$ contained in the vehicle is 0.013 grams / liter. The quality standard of lead $(\mathrm{Pb})$ in air is $0.025-0.04 \mathrm{gr}$ / $\mathrm{Nm}^{3}$ [14].

Characteristics included of soil weight, soil porosity, water level, soil texture and determination of soil class, while the soil chemistry characteristics included of C-organic compositions, Total- $\mathrm{N}, \mathrm{C} / \mathrm{N}$ ratio, organic matters and $\mathrm{P}$ Total in soil, could be uses as recommendation in treatment of continuously and safe environment of agroecosystem crop yield [12].

According to the Environment Project Agency (2007), about $25 \%$ of lead $(\mathrm{Pb})$ remains in the engine and the other $75 \%$ will pollute the air as exhaust fumes. $\mathrm{Pb}$ emissions from exhaust gases will still cause air pollution wherever the vehicle is located, the stages are as follows: as much as $10 \%$ will pollute the location within a radius of less than $100 \mathrm{~m}, 5 \%$ will pollute the location within a $20 \mathrm{~km}$ radius, and another $35 \%$ carried away in the atmosphere a considerable distance. $\mathrm{Pb}$ substances released from motorized vehicles are on average measuring $0.02-0.05 \mu \mathrm{m}$ by $60-70 \%$. The smaller the particle size the longer the settling time [6]. Therefore we need landscape plants that are planted in various roads and parks in Surabaya City, including Kana (Cana sp) and Butterfly (Bahuinia purpurea). Both plants have different habitus, namely herbs, and shrubs. The difference in habitus is based on the architecture of a plant. Habitus is usually clarified again with a range of sizes that can be found in natural conditions [15]. Plant habitats include herbs, shrubs, shrubs, trees, lianas, epiphytes and parasites. In this study only studied two types of habitus including herbs and shrubs. Herbaceous habitus used is the Kana (Cana sp.) Shrub habitus which is used as Butterfly (Bahuhinia purpurea). Both plants are dominantly planted around the Surabaya city highway. When the growth is observed, these two plants look good growth, which is reviewed by the color of the leaves that the average green does not show signs of contaminated pollutants. Although both of these plants grow in the area of Surabaya that is crowded with vehicles, it is likely to be polluted by air pollutants. Plant conditions like this can be assessed for their potential as pollutant absorbents. From a study of the two plants selected, 
namely kana and butterfly are plants that are suitable for the needs of urban forest plants [5].

Studies related to the potential of these two plants in absorbing heavy metals have not been many. The objectives of this research are to: Evaluate the ability of $\mathrm{Pb}$ accumulation on Kana and Butterfly leaves exposed to motor vehicle emissions on Jalan Ahmad Yani, Diponegoro and Wiyung, Surabaya, Analyze the relationship between lead $\mathrm{Pb}$ accumulated in Kana and Butterfly leaves with chlorophyll content produced.

\section{MATERIALS AND METHODS}

The research sample was taken at three sampling locations including Ahmad Yani Street, Diponegoro Street and Wiyung Street Surabaya City. The study was conducted in April - July 2017. Analysis of $\mathrm{Pb}$ metal content in Kana and Butterfly leaves using AAS (Atomic Absorption Spectrophotometry) was conducted at the Nutrition Laboratory of Airlangga University, while the analysis of chlorophyll levels of $a, b$ and total was carried out in the Laboratory of Physiology, Department of Biology, Faculty of Mathematics and Natural Sciences, Surabaya State University.

\section{A. Materials}

The tools in this study were scissors, tweezers, plastic bags, ovens, drop pipettes, glass beakers, cuvettes, spectrophotometers, spectrophotometers, analytical scales, 50 $\mathrm{ml}$ size flasks, $100 \mathrm{ml}$ size flasks, destructive squash, filter paper, AAS (Atomic Absorption Spectrophotometry) Type AA-700, test tube, porcelain cup (mortal), pestle, insulation, ruler, funnel, tissue and label paper.

The materials used in this study were leaves of Kana and Butterfly; nitric acid (HNO3); perchloric acid (HClO4); aquades; $95 \%$ alcohol and 1000 ppm $\mathrm{Pb}$ standard solution.

\section{B. Methods}

\section{1) Preparation Stage}

This stage is carried out by conducting a point determination survey for sampling, preparation of tools and materials for the sampling stage.

\section{2) Sampling Phase}

Samples of Kana and Butterfly leaves were taken by purposive sampling method on three roads, namely Ahmad Yani Street, Diponegoro and Wiyung Surabaya City. The collection is carried out at 10.30-12.00. Each station selected 3 stations, from each station 15 leaf samples were taken for analysis. The leaves are cut from the stem by using scissors carefully. Furthermore, the sample was taken using tweezers and put into a plastic bag labeled.

3) Calculation of Leaf Chlorophyll Levels

- Weighing one gram of Kana and Butterfly leaves that are still fresh, then cut into small pieces.

- Grind the leaves in a porcelain mortar until smooth.

- Extract the scours of the leaves using $100 \mathrm{ml}$ of $95 \%$ alcohol.

- Filter the extract using filter paper until the final volume of the filtrate is less than $100 \mathrm{ml}$, adding $95 \%$ alcohol again.
- Calibrate the spectrophotometer first using $95 \%$ alkolol solvent before measuring.

- Measuring the levels of chlorophyll filtrate using a spectrophotometer at a wavelength of $649 \mathrm{~nm}$ and 665 $\mathrm{nm}$.

- Record the absorptive value (Optical Density) of the solution.

- Chlorophyll a levels, chlorophyll b levels and total chlorophyll levels can be calculated by the formula of Wintermans and de Mots as follows (Rahayu et al., 2014):

> Chlorophyll a: 13.7 x OD 665 - 5.76 OD $649(\mathrm{mg} / \mathrm{l})$

$>$ Chlorophyll b: 25.8 x OD $649-7.7$ OD 665 (mg / l)

> Total chlorophyll: 20.0 x OD $649+6.1$ OD $665(\mathrm{mg} / \mathrm{l})$

4) Measurement Phase of Lead (Pb) Leaves

- Wet Destruction Kana and butterfly leaves

- Atomic Absorption Spectrophotometry (SSA) Reading

5) Data Retrieval Techniques

Retrieval of lead $(\mathrm{Pb})$ data on Kana and butterfly leaves was carried out using AAS (Atomic Absorption Spectrophotometry) while leaf chlorophyll content data using a spectrophotometer with a wavelength of $649 \mathrm{~nm}$ and $665 \mathrm{~nm}$.

\section{6) Data Analysis Techniques}

Data on the relationship between lead $(\mathrm{Pb})$ and chlorophyll content in leaves were analyzed using Linear Regression. The absorption ability of lead $(\mathrm{Pb})$ by Kana and Butterfly leaves to vehicle intensity and chlorophyll content were analyzed quantitatively descriptively.

\section{RESULTS}

\section{A. Lead Levels $(\mathrm{Pb})$ on Leaves of Bauhinia and Canna}

TABLE I. LEAD LEVELS (PB) ON LEAVES OF BAUHINIA AND CANNA EXPOSED TO MOTORIZED VEHICLE EMISSIONS ON SEVERAL ROADS IN SURABAYA

\begin{tabular}{|c|c|c|c|c|}
\hline $\begin{array}{c}\text { Types of } \\
\text { Plants }\end{array}$ & location & $\begin{array}{c}\text { Lead Levels } \\
(\mathbf{P b}) \text { in } \\
\text { Leaves } \\
(\mathbf{p p m})\end{array}$ & $\begin{array}{c}\text { Average } \\
\text { Lead } \\
\text { Levels in } \\
\text { Leaves } \\
(\mathbf{p p m})\end{array}$ & $\begin{array}{c}\text { Average } \\
\text { Traffic } \\
\text { Volume } \\
\text { (Unit) }\end{array}$ \\
\hline \multirow{3}{*}{ Bauhinia } & Dhmad Yani & $0.908 \pm 0.011$ & \multirow{2}{*}{$0.834 \pm$} & 204,736 \\
\cline { 2 - 3 } & Diponegoro & $0,885 \pm 0,010$ & 154,850 \\
\cline { 2 - 3 } Canna & Wiyung & $0,710 \pm 0,011$ & 0.108 & 24,212 \\
\hline & Ahmad Yani & $0.828 \pm 0.007$ & \multirow{2}{*}{$0.786 \pm$} & 204,736 \\
\cline { 2 - 3 } & Diponegoro & $0,851 \pm 0,014$ & 154,850 \\
\cline { 2 - 3 } & Wiyung & $0.678 \pm 0.054$ & 0.093 & 24,212 \\
\hline
\end{tabular}

TABLE II. CHLOROPHYLL LEVELS (MG / L) OF BAUHINIA LEAVES AND LEAD (PB) CANNA IN THE AIR

\begin{tabular}{|c|c|c|c|}
\hline \multirow{2}{*}{ Type of Plant } & Location & $\begin{array}{c}\text { Leaf Chlorophyll } \\
\text { Level (mg / L) }\end{array}$ & $\begin{array}{c}\text { Average Leaf } \\
\text { Chlorophyll } \\
\text { Level (mg / L) }\end{array}$ \\
\hline \multirow{2}{*}{ Bauhinia } & Ahmad Yani & $31.866 \pm 8.984$ & \multirow{2}{*}{$34.677 \pm 2.663$} \\
\cline { 2 - 3 } & Diponegoro & $37.163 \pm 12.891$ & \\
\cline { 2 - 3 } & Wiyung & $35.002 \pm 4.950$ & \multirow{2}{*}{$16.733 \pm 2.913$} \\
\hline \multirow{2}{*}{ Canna } & Ahmad Yani & $13.431 \pm 1.746$ & \\
\cline { 2 - 3 } & Diponegoro & $17.832 \pm 3.391$ & \\
\cline { 2 - 3 } & Wiyung & $18.938 \pm 3.110$ & \\
\hline
\end{tabular}


TABLE III. ENVIRONMENTAL PHYSICS AND CHEMICAL PARAMETERS

\begin{tabular}{|c|c|c|c|c|c|c|}
\hline Station & $\begin{array}{c}\text { Groun } \\
\mathbf{d} \\
\text { temper } \\
\text { ature } \\
\left({ }^{\circ} \mathbf{C}\right)\end{array}$ & $\begin{array}{c}\text { Air } \\
\text { temper } \\
\text { ature } \\
\left({ }^{\circ} \mathbf{C}\right)\end{array}$ & $\begin{array}{c}\text { Soil } \\
\text { moisture } \\
(\mathbf{R h \%})\end{array}$ & $\begin{array}{c}\text { Air } \\
\text { humidi } \\
\text { ty } \\
(\mathbf{R h \% )}\end{array}$ & $\begin{array}{c}\text { Soil } \\
\mathbf{p H}\end{array}$ & $\begin{array}{c}\text { Light } \\
\text { intensity } \\
(\mathbf{C d})\end{array}$ \\
\hline $\begin{array}{c}\text { Ahmad } \\
\text { Yani }\end{array}$ & 19 & 24.2 & 83.37 & 53 & 7.6 & 9716.67 \\
\hline $\begin{array}{c}\text { Diponeg } \\
\text { oro }\end{array}$ & 18.67 & 36.03 & 86.67 & 47.67 & 7.6 & 9556.67 \\
\hline Wiyung & 18.67 & 35.03 & 73.3 & 42.67 & 7.6 & 9690 \\
\hline
\end{tabular}

\section{B. Lead content $(\mathrm{Pb})$ on leaves}

Lead $(\mathrm{Pb})$ is a heavy metal that is very toxic, can be detected practically on all inanimate objects in the environment and throughout the biological system. Lead content $(\mathrm{Pb})$ on Bauhinia and Canna leaves exposed to motor vehicle emissions on some of the highest roads in Surabaya are Bauhinia plants $(0.834 \pm 0.108)$. This is because the ability of plants to absorb lead $\mathrm{Pb}$ is strongly influenced by the condition of the plant's leaf surface. Leaves that have pubescent or leaves that have a rough surface (wrinkled) have a higher ability to absorb lead than leaves that have a more slippery and even surface. The same thing was stated by Siringiringo [23] that the ability of leaves to absorb a pollutant is influenced by the morphological characteristics of the leaves, such as the size and shape of the leaves, the presence of hair on the leaf surface and also the texture of the leaves [23]. As mentioned before, plants can absorb heavy metals from leaves and there are aerosol deposits attached to the leaves [25]. This has an effect on the research, because some of the element's contents will be lost during washing before being analyzed. The amount of material lost depends on the washing material and leaf texture [9]. Many factors affect the levels of elements in plants, including plant types, types of plant tissues, the content of elements in the soil, the presence of elements, the distance of plants from pollutant sources, seasons, weather conditions, and absorption of aerosols from leaves. Because of these factors the content of heavy metal elements varies greatly. Ahmad Yani Street found a lot of $\mathrm{Pb}$ exposure in leaves $0.908 \pm 0.011 \mathrm{mg} / \mathrm{L}$ because the number of motorized vehicles passed more than other roads in the study. Motorized vehicles are the main cause of air pollution in the city of Surabaya, especially $\mathrm{Pb}$ metal pollution. Motorized vehicles are classified as moving pollutants so that the distribution of pollutants emitted from motorized vehicles has a spatial distribution pattern that extends [11].

$\mathrm{Pb}$ entering plants through leaves depends on the ability of the leaves to absorb $\mathrm{Pb}$ from air sources, depending on the specific morphology of the leaves. Delicate leaves absorb heavy metals from the atmosphere [18]. Pb binds organic matter in the media. The factors that influence the availability of $\mathrm{Pb}$ extraction are media particle size, ion exchange capacity, plant factors such as root surface area, root exudate, mycoryhizae, and transpiration rate [16].
$\mathrm{Pb}$ metal exists in various forms in natural resources throughout the world and now one of the most abundant and evenly distributed trace metals in plants can be contaminated by $\mathrm{Pb} . \mathrm{Pb}$ accumulates above 8 inches from the ground and is very moving, soils contaminated with $\mathrm{Pb}$ will not change to normal if there are no corrective actions. Because $\mathrm{Pb} 2+$ cannot be broken down, once a land is contaminated, in the long run $\mathrm{Pb}$ remains a source of pollutants in the environment.

\section{Chlorophyll content $(\mathrm{mg} / \mathrm{l})$ leaves}

Chlorophyll content ( $\mathrm{mg} / \mathrm{l}$ ) of Bauhinia and Canna leaves exposed to lead $(\mathrm{Pb})$ in the air showed that Bauhinia leaves were higher than Canna leaves, which amounted to $34.677 \pm$ $2.663 \mathrm{mg} / \mathrm{l}$ for Bauhinia leaves and $16.733 \pm 2.913 \mathrm{mg} / 1$ for Canna leaves. . The anatomical network of leaves is composed of upper and lower epidermal tissue, mesophyll tissue (composed of palisade tissue and spongy tissue). Chlorophyll as a green pigment that functions as an absorbent of light in photosynthetic activities and takes place in the mesophyll tissue of the leaves will decrease in line with the increase in air pollution. Lead $(\mathrm{Pb})$ enters through the epidermis, then passive transport occurs to the mesophyll layer. Mesophyll layer is an area that contains chlorophyll. The palisade layer contains a lot of chloroplasts. The formation of chloroplasts is influenced by $\mathrm{H}_{2} \mathrm{O}$ and $\mathrm{O}_{2}$. The entry of air pollutants through the leaf gap will settle around mesophyll tissue, in which there are many chloroplasts. Space between cells is a place for exchanging $\mathrm{H}_{2} \mathrm{O}, \mathrm{O}_{2}$, and $\mathrm{CO}_{2}$ that is found around mesophyll tissue. If pollutants enter will affect the components in the space between cells, causing inhibition of chloroplasts formation resulting in a decrease in chlorophyll. Decrease in chlorophyll content resulting in a decrease in photosynthesis rate so that it will affect the rate of growth and development of plants [16]. Added that the closer the plant to the source of exhaust gas content of motorized vehicles, the greater the chlorophyll will experience degradation, so that the levels become lower [18]. Formation of chloroplasts is strongly influenced by mineral nutrients such as $\mathrm{Mg}$ and Fe. Excessive heavy metal entry into plants will reduce the intake of $\mathrm{Mg}$ and $\mathrm{Fe}$, causing changes in the volume and amount of chloroplasts [20]

Accumulation of heavy metal lead $(\mathrm{Pb})$ in leaves results in growth inhibition and decreased productivity. This is because lead $(\mathrm{Pb})$ is able to change the absorption of nutrient minerals because of the influence between ions, inhibition of photosynthesis process, especially Rubisco activity in the Calvin cycle, and inhibition of chlorophyll biosynthesis [19]. The presence of lead $(\mathrm{Pb})$ takes part in the disruption of photosynthesis due to disruption of enzymes that contribute to chlorophyll biosynthesis, namely aminolevulinic acid (ALAD) which catalyzes the formation of porphobilinogen [7]. Heavy metal lead $(\mathrm{Pb})$ can damage the structure of chloroplasts in the structure of grana [6]. Kramer and Kozlowski (19790 [18], state that most pollutants in the air will reduce photosynthesis both directly and indirectly. This is caused by damage to tissues to carry out photosynthesis and disruption in stomata opening. Pollutants can cause physiological damage in plants long before physical damage occurs. This is called hidden 
damage, which can be a decrease in the ability of plants to absorb water, slow cell growth, or incomplete stomata opening. Total leaf area of a plant affected by air pollution will decrease, because of the inhibition of the formation and expansion of leaves and the increasing number of leaves that fall.

The average $\mathrm{Pb}$ particle size is only $0.2 \mu \mathrm{m}$ [10], so it can enter the leaf tissue through the stomata cleft and settle in it. How to enter $\mathrm{Pb}$ particles through a passive absorption process. Absorption through leaves can occur because $\mathrm{Pb}$ particles in the air fall and settle on the leaf surface. The rough, hairy and wide leaf surface will be easier to catch particles than the smooth, hairless and narrow leaf surface [21]. Although the mechanism of $\mathrm{Pb}$ entry into leaf tissue through a passive absorption process, [18] argues that among tissues in plant organs, leaves are a rich part of chemical elements, thus the likelihood of accumulation of $\mathrm{Pb}$ in the leaf tissue will be greater. $\mathrm{Pb}$ content greater than $10 \mu \mathrm{g} / \mathrm{kg}$ dry weight of leaves will cause overall plant growth disruption. As an element of dangerous toxic heavy metals (LB3) the element of lead is very dangerous if it is consumed exceeding the quality standards permitted by FAO and the Directorate General of $\mathrm{POM}, \mathrm{MOH}$. The negative effect of $\mathrm{Pb}$ is a change in biochemical functions and functions in the body, especially in the work of membranes and enzymes. The interaction of $\mathrm{Pb}$ with proteins composed of amino acids with sulfide groups ($\mathrm{SH})$ will cause a great poisoning effect, even inorganic lead $\left(\mathrm{Pb}_{2}+\right)$ can inhibit the growth of children because it damages the growth of bone tissue [22]. In addition, heavy metal elements have a very large affinity for sulfur compounds. The heavy metal can damage the sulfur bond in the enzyme, so the enzyme becomes unstable and loses its function. Carboxylic acid groups $(-\mathrm{COOH})$ and amino groups $\left(-\mathrm{NH}_{2}\right)$ in amino acids can also be attacked by heavy metals. Heavy metals can precipitate

The mechanism of inhibition of chlorophyll biosistesis that occurs in chloroplasts due to the entry of lead $(\mathrm{Pb})$ is by blocking the performance of the enzymes needed in the chlorophyll biosynthesis process. The enzymes that play a role in chlorophyll biosynthesis include porphobilonogen deaminase, aminolevulinic acid (ALA) dehydratease, and protochlorophyllide. The presence of lead $(\mathrm{Pb})$ in plant tissues is directly related to the activity of porphobilonogen deaminase and aminolevulinic acid (ALA) dehydrate which can also inhibit porphyrin synthesis which is part of chlorophyll (Prasad and Prasad, 1990). If the coenzyme which is bound by an enzyme is not the proper metal ion, the function of the enzyme will be disrupted [10].

The excess lead $(\mathrm{Pb})$ concentration in the leaves causes the performance of plastoquinone contained in the chloroplast thylakoid membrane to be disrupted. The plasticoquinone molecule is a peripheral protein that is bound free to the surface of the thylakoid membrane. The plasticoquinone molecule functions as an electron carrier that plays an important role in photosynthetic chemical reaction, which in turn can disrupt the formation of ATP and NADPH [6]. The negative effects of pollutants are on the rate of carbon dioxide assimilation. The biggest effect of gas pollutants is leaf injury (necrosis and leaf fall). Chlorophyll is very sensitive and easily affected when exposed to environmental conditions at certain times at certain levels. The relationship between chlorophyll levels and gas pollutants is inversely proportional to the chlorophyll content of plants [24].

Physiological phosphate compounds, in addition to catalyzing their decomposition [19]. However, naturally the body can tolerate heavy metal lead at low concentrations, because in addition to the food we consume heavy metals can also enter the human body through the respiratory system or directly through the surface of the skin. Pb that enters the body at low concentrations will be removed through urine, hair, sweat, nails and feces. From the results of research, it was found that the $\mathrm{Pb}$ content in human hair was higher when compared to $\mathrm{Pb}$ in drinking water and the vegetables consumed. At high concentrations, especially if it has exceeded the safe threshold, $\mathrm{Pb}$ in the blood will affect the activity of the ALAD delta enzyme. $\mathrm{Pb}$ can affect the activity of this enzyme in the formation of hemoglobin $(\mathrm{Hb})$ in red blood cells. Disruption of the activity of the delta ALAD enzyme in producing hemoglobin can cause anemia, which is known as a bloodless disease [22].

This has an impact on health, namely: an increase in the number of adult deaths due to cardiovascular disease and coronary heart disease, an increase in cases of hypertension, decreased IQ in children, and can cause intestinal disorders, anemia, nephoropathy (kidney) and encephalopathy (brain). Therefore the results of this study would be considered by the relevant authorities to make more stringent provisions and more intensive supervision of the community around the Jagorawi toll road so as not to take the leaves and bark of cinnamon plants as food. Despite the issuance of a policy on the prohibition on the use of leaded gasoline and DKI Jakarta has been set free from the use of leaded gasoline in 2003, and the recommended use of unleaded gasoline (Super-TT) has been issued since 2001, but until now for the Jakarta area still sold a lot of gasoline leaded and for areas outside Jakarta there is no lead-free gasoline, even though vehicles passing on the Jagorawi toll road to Jakarta generally still refuel outside Jakarta [17]. Air pollution conditions are expected to be reduced and air quality will improve if the policy of using unleaded gasoline has been implemented properly and supported by Pertamina as an institution that provides unleaded gasoline. The availability of unleaded gasoline for other regions outside Java is expected to be realized in 2003 or still approximately one year after this research was carried out. Therefore, the accumulation of lead heavy metal elements in plants in the Jagorawi toll road will continue to increase, especially for perennial plants. Because this condition endangers the surrounding community.

\section{CONCLUSION}

Cana and Butterfly can accumulate $\mathrm{Pb}$ in leaves. The type of plant does not affect the $\mathrm{Pb}$ levels in the leaves of Kana and butterfly, but the planting location affects the $\mathrm{Pb}$ levels of both plants. The levels of $\mathrm{Pb}$ in the leaves of the two plants planted 
on Jalan Ahmad Yani and Diponegoro are higher than those planted on the Wiyung road. Pd levels in leaves do not affect chlorophyll levels

\section{REFERENCES}

[1] R.J. Antari and I.K. Sundra, "Plumbum content on shade plants in the city of Denpasar," J. Department of Biology FMIPA-UNUD, 2009.

[2] W. Boediningsih, "Impact of Traffic Density on Air Pollution in Surabaya City," J. of the Faculty of Law Vol. XX (20). Narotama University Surabaya, 2011.

[3] S.F. Chen and C.Y. Huang, "Influence of cadmium on growth of root vegetable and accumulation of cadmium in the edible root," Int. J. Appl. Sci. Eng., vol. 4, pp. 243-252, December 2006

[4] R.S. Dewi, Analysis of Air Lead Levels, Blood Lead and Its Impact on Hemoglobin Levels of Market Traders in Ambon City, Unpublished thesis, Makassar: Postgraduate Program, UNHAS, 2009.

[5] Surabaya City Transportation Agency, Report of the 2016 Traffic Performance Survey, Surabaya City Government, 2016.

[6] J.E. Fergusson, The Heavy Element: Chemistry, Environmental Impact and Health Effect, England: Pergamon Press inc, 1991

[7] I.N. Gostin, Air pollution effect on the leaf structure of some Fabaceae species, 2009. (Online), (https://www.repository.unhas.ac.id, accessed November 17, 2016)

[8] D. Gusnita, "Reflection of Heavy Lead Metal $(\mathrm{Pb})$ in Air and Leaded Gasoline Removal Efforts," Aerospace News, vol. 13(3), 2012.

[9] N. Hendrasarie, "Study of the effectiveness of plants in absorbing $\mathrm{Pb}$ content in the air," J. of Eng. Plan., vol. 3 (2), 2007.

[10] S.R. Hidayati, Analysis of Stomata Characteristics, Chlorophyll Levels, and Heavy Metal Contents on the Leaves of the Tree Protectors of the Sidoarjo Porong Mud Road, Essay, Published, Sinstek Faculty and Technology, State Islamic University of Malang, Poor, 2009.

[11] M. Jamhari, "Relationship of Lead $(\mathrm{Pb})$ Content in Air with $\mathrm{Pb}$ in Talus Lichen Xanthoparmelia xanthofarinosa," Paper presented in the VIII National Seminar on Biological Education, Palu, 2011.

[12] T. Landberg, and M. Greger, "Differences in uptake and tolerance to heavy metals in Salix from polluted and unpolluted areas," Applied Geochemistry, vol. 11, pp. 175-80, March 1996.

[13] T.P. Librawati, Analysis of Pb Contamination on Leaf Onions (Allium fistulosum L) in Dieng Wonosobo Region, Essay, Published, Purwokerto Unsoed Faculty of Biology, 2005.

[14] H.J. Mukono, Air pollution and its effects on respiratory tract disorders. Surabaya: Airlangga University Press, 2002.

[15] NASA and ALCA, Interior Landscape Plants for Indoor Air Pollution Abatement. National Aeronautics and Space Administration's John C. Stennis Space Center at the Stennis Space Center for Science and Technology Laboratory, MS 39529-6000, 1989.

[16] Y. Novita and T. Purnomo, Absorption of Lead Metals (Pb) and Chlorophyll Elodea Canadensis Levels in Pulp and Paper Mill Liquid Waste. LenteraBio Journal. vol. 1 (1), pp. 1-8, 2012.

[17] Center for Environmental Impact Management (PUSARPEDAL). 2011 "Assessment of Lead $(\mathrm{Pb})$ in Ambient Air in Serpong and Surroundings". Tangerang: Deputy for the Development of Technical Facilities and Capacity Building of the Ministry of Environment.

[18] Rahayu, Analysis of Chlorophyll and Pb Heavy Metal Content in Leaf Networks Due to Traffic Pollution," J. of UGM Environmental Research Center, vol. 2 (5), pp. 53-66, 1995.

[19] M.M. Rahman, L. Haoliang, Y. Chonling, S. Hoque, Heavy Metal Hyper-accumulation in Plans and Metal Distribution in Soil on Tannery and Dying Industries polluted area in Bangladesh," Academic Open Internet J., vol. 21, 2007.

[20] M.N.S. Rangkuti, "Heavy Metal Lead in Cinnamomum burmani Bl) on the Left Side of Jagorawi Toll Road," Biosmart J., vol. 6 (2), pp. 139142, 2004.

[21] A. Saleha, Alimuddin and R. Gunawan, "Distribution of Lead Metal $(\mathrm{Pb})$ on Wedelia Plants (Wedelia Trilobata (L.) Hitch) Due to Motor
Vehicle Emissions in Several Roads of Samarinda City," Mulawarman Chemical J. vol. 10 (2), pp. 80-84, 2013.

[22] D.N. Santi, "Air Pollution by Lead $(\mathrm{Pb})$ and Countermeasures," J. of the Faculty of Medicine. vol. 2, pp. 5-6, 2001.

[23] H. Siringoringo, "The Ability of Several Types of Urban Forest Plants in Absorbing Lead Particulates," Bul. Pen. Forest, 2000.

[24] A. Solihin, Leaf Morphology, Chlorophyll and Stomata Glodogan Levels (Polyalthia longifolia) in Regions with Different Levels of Vehicle Emission Exposure in Yogyakarta, Essay, Yogyakarta: State Islamic University Sunan Kalijaga, 2014.

[25] S. Sulistiana, "Lead Absorption Ability $(\mathrm{Pb})$ in Some Puring Plant Cultivars (Codiaeum variegatum)," J. of Mathematics, Sanis, and Technology, vol. 16 (1), pp. 10-17, 2015. 